OPEN ACCESS

Edited by:

Xinpeng Fan,

East China Normal University, China

Reviewed by:

Yuri Mazei,

Lomonosov Moscow State University,

Russia

Sheng-Fang Tsai,

National Taiwan Ocean University,

Taiwan

${ }^{*}$ Correspondence:

Mann Kyoon Shin

mkshin@ulsan.ac.k

Lifang $\mathrm{Li}$

qd_liliy@sina.com

${ }^{\dagger}$ These authors have contributed equally to this work

Specialty section:

This article was submitted to

Aquatic Microbiology,

a section of the journal

Frontiers in Microbiology

Received: 27 April 2021

Accepted: 09 August 2021 Published: 16 September 2021

Citation:

Song W, XU D, Chen X, Warren A, Shin MK, Song $W$ and Li L (2021)

Overview of the Diversity, Phylogeny and Biogeography of Strombidiid

Oligotrich Ciliates (Protista, Ciliophora), With a Brief Revision and a Key to the Known Genera.

Front. Microbiol. 12:700940. doi: 10.3389/fmicb.2021.700940

\section{Overview of the Diversity, Phylogeny and Biogeography of Strombidiid Oligotrich Ciliates (Protista, Ciliophora), With a Brief Revision and a Key to the Known Genera}

\author{
Wen Song ${ }^{1 \dagger}$, Dapeng $\mathrm{Xu}^{2 \dagger}$, Xiao Chen ${ }^{1 \dagger}$, Alan Warren ${ }^{3}$, Mann Kyoon Shin ${ }^{4 *}$, \\ Weibo Song ${ }^{1,5}$ and Lifang $\mathrm{Li}^{1 *}$
}

\footnotetext{
${ }^{1}$ Laboratory of Marine Protozoan Biodiversity and Evolution, Marine College, Shandong University, Weihai, China, ${ }^{2}$ State Key Laboratory of Marine Environmental Science, College of Ocean and Earth Sciences, Xiamen University, Xiamen, China, ${ }^{3}$ Department of Life Sciences, Natural History Museum, London, United Kingdom, ${ }^{4}$ Department of Biological Science, University of Ulsan, Ulsan, South Korea, ${ }^{5}$ Laboratory for Marine Biology and Biotechnology, Qingdao National Laboratory for Marine Science and Technology, Qingdao, China
}

Strombidiids are common free-living ciliates that have colonized coastal and open oceanic waters across the world. In recent years, numerous new taxa and gene sequences of strombidiids have been reported, revealing a large diversity of both their morphologic and genetic features. Here, we compare the taxonomic characters of all genera in the family Strombidiidae, provide a key to their identification, and investigate their molecular phylogeny. In addition, we analyze their regional distribution based on faunal data accumulated in China and attempt to infer their global distribution based on SSU rRNA gene sequence data. The current work revises the systematics of strombidiids based on morphologic, phylogenetic, and biogeographic evidence and provides a genus-level review of marine strombidiids.

Keywords: ciliary pattern, identification, morphology, Oligotrichia, planktonic ciliates

\section{INTRODUCTION}

Since the proposal of the "microbial loop" hypothesis (Azam et al., 1983), ciliates have been recognized as one of the major components of marine ecosystems (Azam and Malfatti, 2007; Fenchel, 2008; de Vargas et al., 2015; Bai et al., 2020a,b; Wang R. et al., 2020; Liu Q. et al., 2021). Ciliates, especially species in the subclass Oligotrichia, play essential roles in the microbial loop as grazers of nano-/picoplankton and as food sources for larger zooplankton including copepods and fish larvae (Song et al., 2009; Hu et al., 2019; Huang et al., 2021). Consequently, oligotrichs have been a focus in the study of marine science, especially their diversity, phylogeny and biogeography (Song et al., 2009; Santoferrara and McManus, 2017; Hu et al., 2019).

Members of the family Strombidiidae Fauré-Fremiet, 1970, are reported to be ubiquitous and to episodically dominate the microzooplankton community in both coastal and oceanic waters (Sherr and Sherr, 1987; Dolan et al., 2013; Sun et al., 2019; Yang et al., 2020). Due to their wide distribution, high abundance, and fast growth rate (Montagnes, 1996; Santoferrara and McManus, 2017), 
numerous studies focusing on the taxonomy and phylogeny of strombidiids have been carried out (e.g., McManus et al., 2010; Agatha, 2011, 2014; Lee et al., 2015; Liu et al., 2015a, 2016; Liu W. et al., 2017; Gao et al., 2016, 2017; Li et al., 2020). The somatic ciliature of most strombidiids usually includes a girdle kinety (GK) and a ventral kinety (VK) although there is considerable variation of these two among the 12 genera of the family Strombidiidae and in some species the ventral kinety is lacking (Lynn, 2008; Song et al., 2009; Agatha, 2011). Since the first strombidiid species, Strombidium sulcatum (Claparède and Lachmann, 1859), was described, over 100 nominal species have been reported worldwide (Shen et al., 2018; Wang et al., 2018, 2019; Küppers et al., 2019; Song et al., 2019; Liu W. et al., 2021). Nevertheless, although the systematics of strombidiids have been frequently discussed, there are many disparities between the molecular and morphological data, especially at the genus and species levels (McManus and Katz, 2009; Agatha and Strüder-Kypke, 2014).

Since strombidiids are common members of the microzooplankton community, their distribution and biogeography have received extensive attention from ecologists. Knowledge of this topic, however, remains scant because data on their biogeography are limited by undersampling worldwide (Agatha, 2011; Lu et al., 2020). In recent years, the diversity of strombidiids in Chinese coastal waters has been extensively studied and almost all known genera in the family Strombidiidae have been recorded (Song W. et al., 2013; Liu W. et al., 2017; Song et al., 2018, 2019; Liu et al., 2019; Hu et al., 2019). Consequently, there is sufficient available data for their distribution in coastal regions of China to be reviewed.

In the last two decades, environmental sequencing-based techniques, e.g., clone library construction, denaturing gradient gel electrophoresis (DGGE), restriction fragment length polymorphism (RFLP), and high-throughput sequencing (HTS), have enabled studies on the distribution of ciliates to be carried out in a culture-independent and taxonomic expertise-free way (López-García et al., 2001; Moon-van der Staay et al., 2001; de Vargas et al., 2015; Xu et al., 2017). The application of environmental sequencing-based techniques has prompted the discovery of new ciliate lineages and previously undiscovered patterns of distribution (Grattepanche et al., 2016; Santoferrara et al., 2016; Sun et al., 2016, 2019; Wang Y.R. et al., 2020). The rapid growth in the number of available SSU rRNA gene sequences allied to detailed observation and documentation of morphological characteristics can thus serve as a reliable database for inferring the taxonomic assignments of environmental sequences. The vast amount of data accumulated in the GenBank database, especially the nearly full-length SSU rRNA gene sequences from clone library studies, also offer the opportunity to infer the biogeographical distribution of strombidiids.

The aims of the present study are to (1) review the systematics of all genera in the family Strombidiidae based on morphological and, where available, molecular data; (2) provide a key to the identification of these genera, and (3) investigate the distribution of marine strombidiids based on taxonomic and SSU rRNA gene sequence data.

\section{MATERIALS AND METHODS}

\section{Phylogenetic Analyses}

The SSU rRNA gene sequences of 65 species of Oligotrichia and Choreotrichia obtained from GenBank were employed to construct phylogenetic trees. Five species (representing five genera) of Halteriida and Hypotrichia were used as outgroup taxa. All 70 sequences were aligned using the MUSCLE algorithm on the GUIDANCE web server with the default parameters (Penn et al., 2010a,b). The ends of the alignment were trimmed using Bioedit (Hall, 1999), yielding a matrix of 1,768 characters. Maximum likelihood (ML) analysis was conducted using RAxML-HPC2 on XSEDE v 8.2.12 (Stamatakis, 2006; Stamatakis et al., 2008) with the optimal model evaluated by the online server CIPRES Science Gateway (Miller et al., 2010). The reliability of internal branches was assessed with a nonparametric bootstrap method featuring 1,000 replicates.

Bayesian inference (BI) analysis was performed with MrBayes 3.2.6 on XSEDE v 3.2.6 (Ronquist and Huelsenbeck, 2003) provided on the CIPRES Science Gateway, with the model $\mathrm{GTR}+\mathrm{I}+\Gamma$ selected by the Akaike information criterion (AIC) in MrModeltest v2 (Nylander, 2004). Markov chain Monte Carlo chains were run for $4 \times 10^{6}$ generations with two parallel runs, each with four simultaneous chains, sampling every 100 generations. The first 10,000 generations were discarded as burnin prior to construction of the consensus tree.

\section{Biogeographic Distribution}

The regional biogeographic patterns of strombidiids were inferred based on a compilation of faunal data from samples collected from coastal regions of China. Variations in the distribution of strombidiid species from 19 coastal sites (Figure 1) were analyzed. The species richness and the community composition in each site were compared. In addition, among these sites, eight ( $\mathrm{a}-\mathrm{h}$ in Figure 1) were located near Qingdao, Shandong Province, northern China, and 11 (i-s in Figure 1) were located in Guangdong and Hainan Provinces, southern China. The communities were compared between northern and southern China.

To infer the possible worldwide biogeographic distribution of the strombidiids, each annotated SSU rRNA gene sequence was blasted against the GenBank The nucleotide collection database and it's nearest environmental neighbor (NEN), i.e., the environmental sequence with the highest sequence similarity, were retrieved (Xu et al., 2020). The locations of the sequences of identified strombidiids and NEN retrieved sequences were marked on a map.

\section{RESULTS AND DISCUSSION}

To date, more than 100 species belonging to 12 genera have been assigned to the family Strombidiidae, including 10 species and seven genera that have been described during the past decade (Agatha, 2011; Liu W. et al., 2017; Hu et al., 2019). In addition, molecular data on strombidiids have been extensively collected in the past 15 years and there are now 46 species 
A

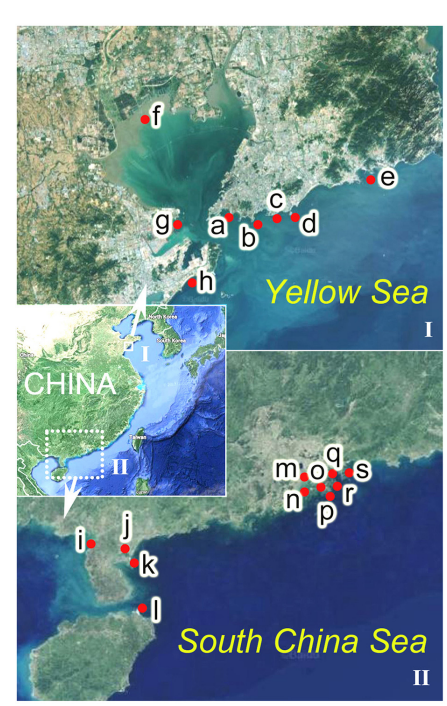

C
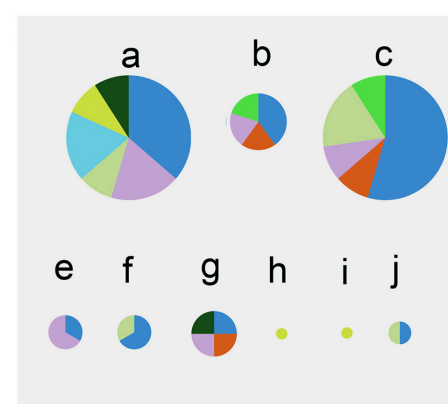

B
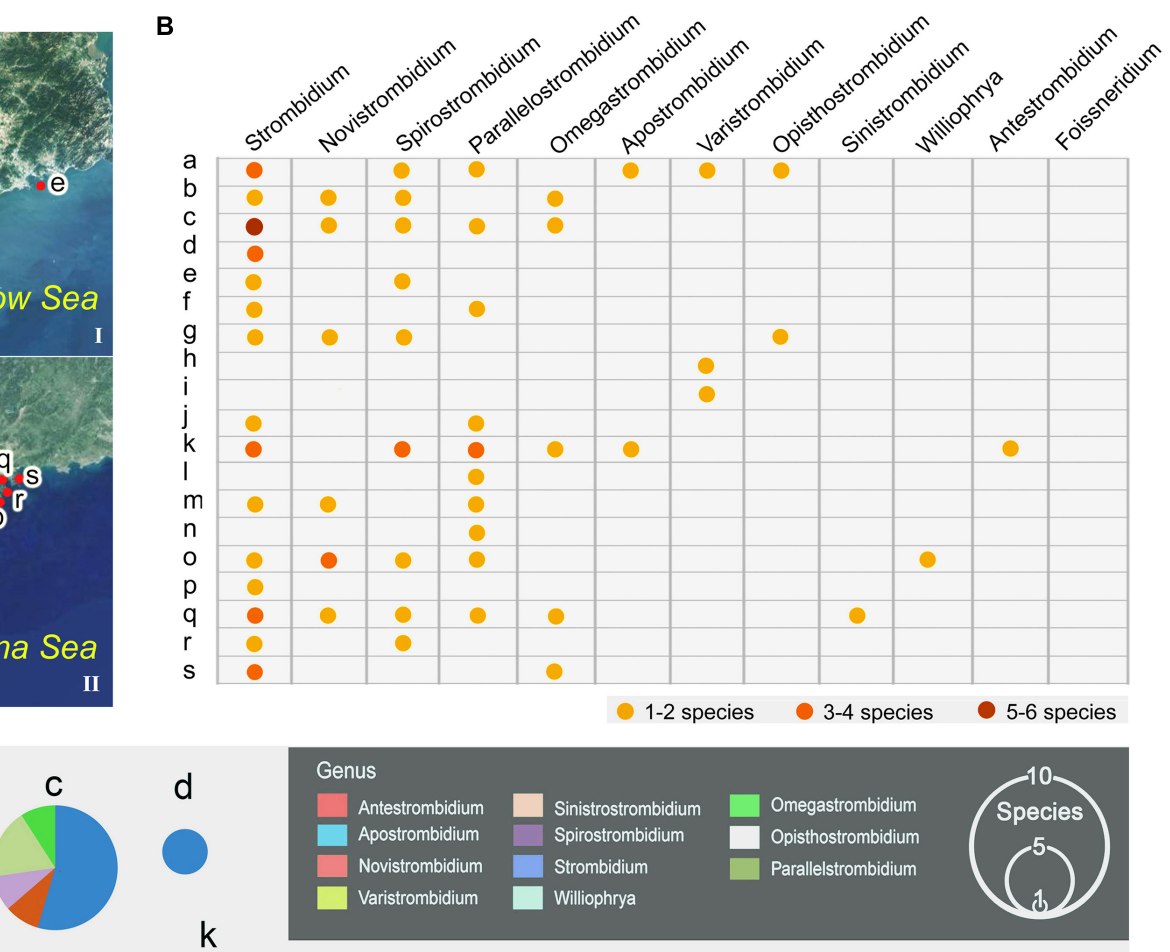

Genus

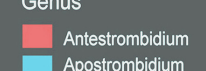

Apostrombidium

Novistrombidium

Varistrombidium k
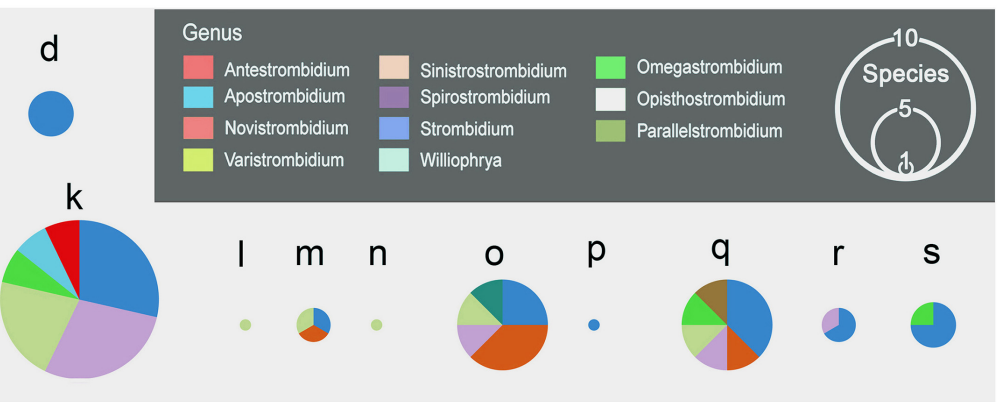

FIGURE 1 | Geographic distribution of the 12 genera of the family Strombididae in China. (A) Showing sampling sites in northern (I) Chinese coastal waters near Qingdao, Shandong Province, and in southern (II) Chinese coastal waters in Guangdong Province and Hainan Province. Red spots on the map mark the locations where species were collected. Location a: Intertidal zone in Qingdao. b: Intertidal zone in Qingdao. c: Coastal waters in Qingdao. d: Beach and reef in Qingdao. e: Beach and reef in Qingdao. f: Intertidal zone in Jiaozhou Bay. g. Intertidal zone in Huangdao. h. Beach in Huangdao. i: Intertidal zone in Zhanjiang. j: Coastal waters in Zhanjiang. k: Mangrove wetland in Zhanjiang. I. Estuary in Haikou. m. Estuary in Guangzhou. n. Coastal waters in Zhuhai. o. Mangrove wetland in Shenzhen. p. Dock in Shenzhen. q. Intertidal zone in Huizhou. r. Mariculture zone in Huizhou. s. Mangrove wetland in Daya Bay. (B) The table shows the occurrence and species diversity of each genus at each sampling site. (C) The pie charts show the species composition of each sampling site, the size of the pie indicates the species richness in each site.

with available SSU rRNA gene sequences (Gao et al., 2017; Song et al., 2020). Although evolutionary relationships of strombidiids have been discussed in several studies, the molecular phylogenies often reveal unexpected relationships that are not consistent with cladograms based on morphological data, especially at the genus level (McManus and Katz, 2009; Agatha and Strüder-Kypke, 2014). The number of new species and genera in the family Strombidiidae is continually increasing, supporting the assertion that $83 \%-89 \%$ of free-living ciliate species are undescribed (Foissner et al., 2008). The taxonomy and systematics of the family Strombidiidae therefore need to be updated.

\section{Taxonomic Review of Genera in the Family Strombidiidae}

The taxonomy of the 12 known genera of Strombidiidae are summarized, including their morphological diagnostic characters, type species, remarks on the history of their establishment, and subsequent revisions (Figures 2, 3).
Genus Antestrombidium (Liu et al., 2015b)

Diagnosis: Strombidiidae with three somatic kineties, i.e., a dextrally spiraled girdle kinety, a circular kinety and a ventral kinety (Liu et al., 2015b).

Type species: Antestrombidium agathae (Liu et al., 2015b)

Liu et al. (2015b) found a strombidiid with a circular kinety fragment. This is a unique character based on which the genus Antestrombidium was established.

Genus Apostrombidium (Xu et al., 2009)

Diagnosis: Strombidiidae with somatic kinety consisting of several fragments that extends toward the posterior end of the cell on both ventral and dorsal sides, with or without a subterminal kinety fragment. Oral primordium located between kinety fragments 1 and 2 (Song et al., 2019).

Type species: Apostrombidium pseudokielum (Xu et al., 2009)

The genus Apostrombidium was established by $\mathrm{Xu}$ et al. (2009) based on the morphological characters of Apostrombidium pseudokielum. Later, two new species were assigned to the genus 

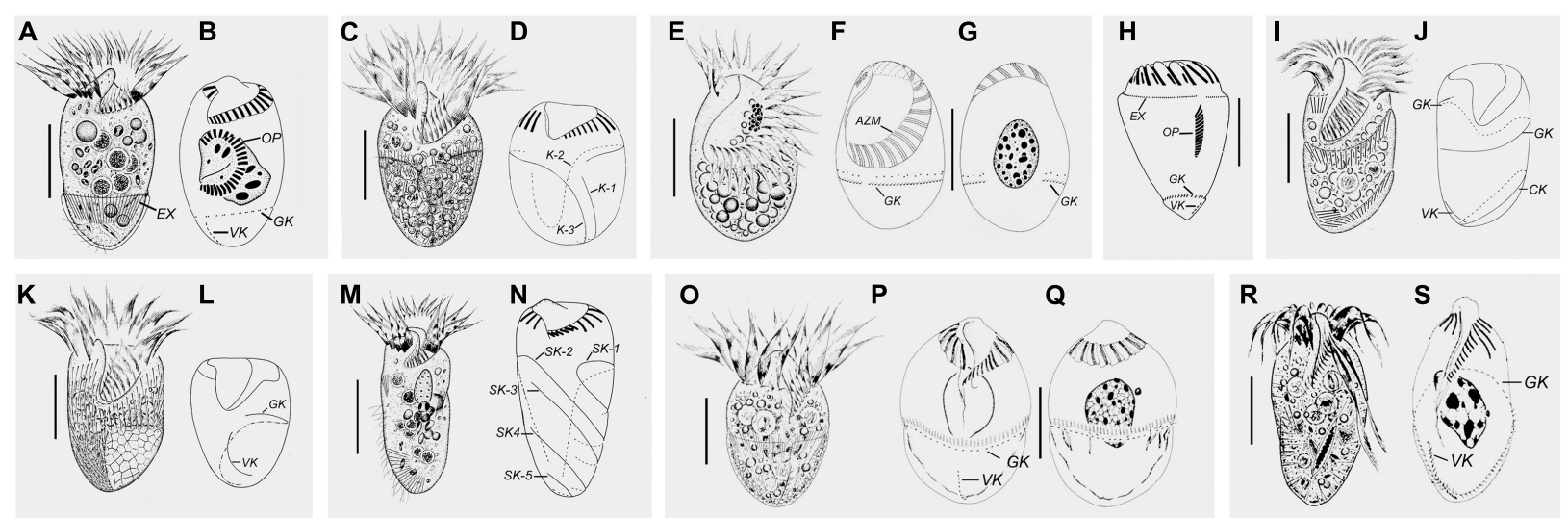

$\mathbf{P}$
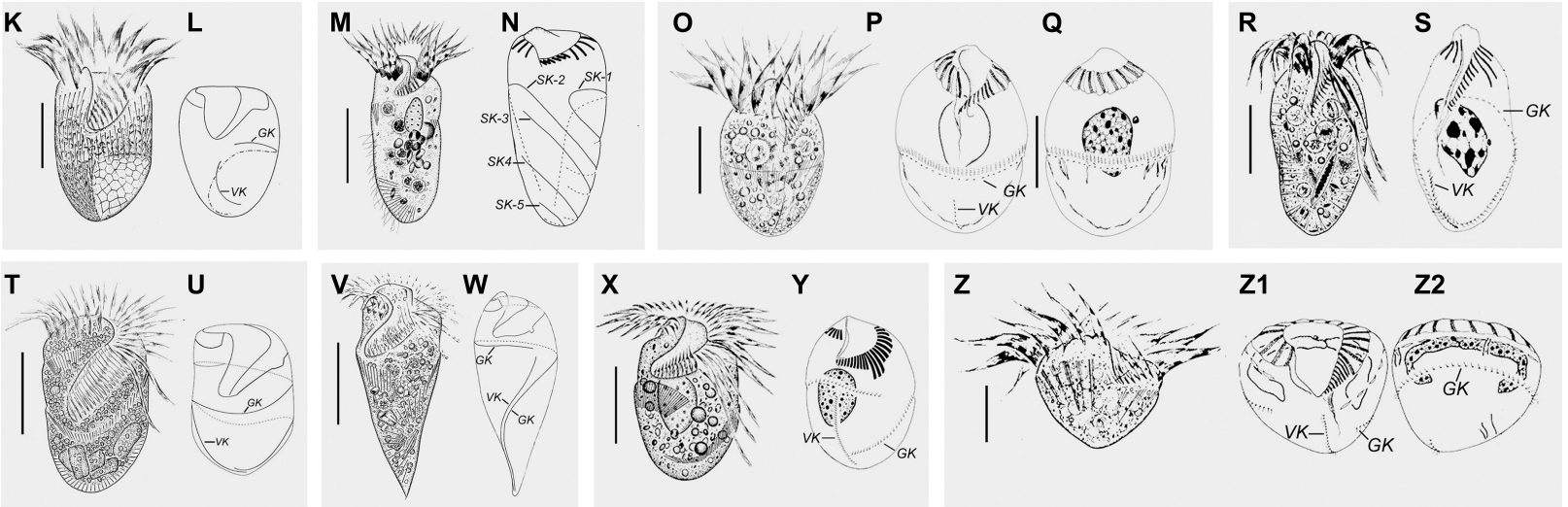

FIGURE 2 | Schematic diagrams from specimens in vivo and after protargol staining of representative species of each strombidiid genus. (A,B) Opisthostrombidium montagnesi (after Xu et al., 2006; Agatha, 2011). (C,D) Apostrombidium parakielum (after Song W. et al., 2013). (E-G) Williophrya maedai (after Liu et al., 2011). (H) Foissneridium constrictum (after Agatha, 2011). (I,J) Antestrombidium agathae (after Liu et al., 2015b). (K,L) Sinistrostrombidium cupiformum (after Liu et al., 2015b). (M,N) Varistrombidium kielum (after Xu et al., 2011). (O-Q) Strombidium sulcatum (after Song et al., 2000). (R,S) Omegastrombidium elegans (after Song et al., 2000). (T,U) Spirostrombidium faurefremieti (after Wang et al., 2018). (V,W) Parallelostrombidium jankowskii (after Song et al., 2018). (X,Y) Novistrombidium (Propecingulum) sinicum (after Liu et al., 2009). (Z-Z2) Novistrombidium (Novistrombidium) testaceum (after Song and Bradbury, 1998). Scale bars $=20 \mu \mathrm{m}$ (C,E,I,K,O,X); $15 \mu \mathrm{m}$ (A,R); $30 \mu \mathrm{m}$ (M,T,Z); $40 \mu \mathrm{m}$ (V)

and the diagnosis for the genus was improved by supplying some new characters (Song W. et al., 2013; Song et al., 2019).

Genus Foissneridium (Agatha, 2011)

Diagnosis: Strombidiidae with oral primordium posterior to the horizontal stripe of extrusome attachment sites and anterior to the horizontal girdle kinety. Ventral kinety longitudinal (Agatha, 2011).

Type species: Foissneridium constrictum (Meunier, 1910; Agatha, 2011)

Extrusome attachment sites arranged along the anterior margin of the girdle kinety are typical in Strombidiidae (Agatha, 2011). In F. constrictum, however, the extrusome attachment sites are pre-equatorial. Moreover, its oral primordium is posterior to the extrusome attachment sites and anterior to the girdle kinety. These are genus-level characters based on which Foissneridium was established.

Although the oral primordium is located anterior to their girdle kinety in both Foissneridium and Opisthostrombidium, the former differs from the latter in that its oral primordium is posterior to the extrusome attachment sites (vs. anterior to extrusome attachment sites). Foissneridium constrictum is the only species in the genus Foissneridium.

Genus Novistrombidium (Song and Bradbury, 1998)

Diagnosis: Strombidiidae with incomplete girdle kinety around the equatorial area that is conspicuously open with a large ventral gap through which ventral kinety extends (Song and Bradbury, 1998).
Type species: Novistrombidium testaceum (Anigstein, 1914; Song and Bradbury, 1998)

The genus Novistrombidium was established by Song and Bradbury (1998). Agatha and Strüder-Kypke (2014) established two subgenera of Novistrombidium, mainly based on different locations of the oral primordium relative to the girdle kinety and the extrusome attachment sites. In the subgenus Novistrombidium (Novistrombidium) Song and Bradbury (1998), the oral primordium is located between a question mark-shaped field of extrusome attachment sites and the girdle kinety. In the subgenus Novistrombidium (Propecingulum) Agatha and Strüder-Kypke (2014), the oral primordium is located anterior to the stripe of extrusome attachment sites that extends alongside the girdle kinety.

Küppers et al. (2019) considered the morphological differences between these two subgenera to be sufficient for them to be elevated to genus rank. However, considering the limited numbers of known species in these two subgenera, we prefer to adopt a conservative approach pending the availability of more morphological and molecular data from more taxa.

Genus Omegastrombidium (Agatha, 2004)

Diagnosis: Girdle kinety horizontally oriented on dorsal side, extending to posterior end of body on ventral side (Agatha, 2004).

Type species: Omegastrombidium elegans (Florentin, 1901; Agatha, 2004)

Florentin (1901) described this species under the name Strombidium elegans. Song et al. (2000) provided a redescription 


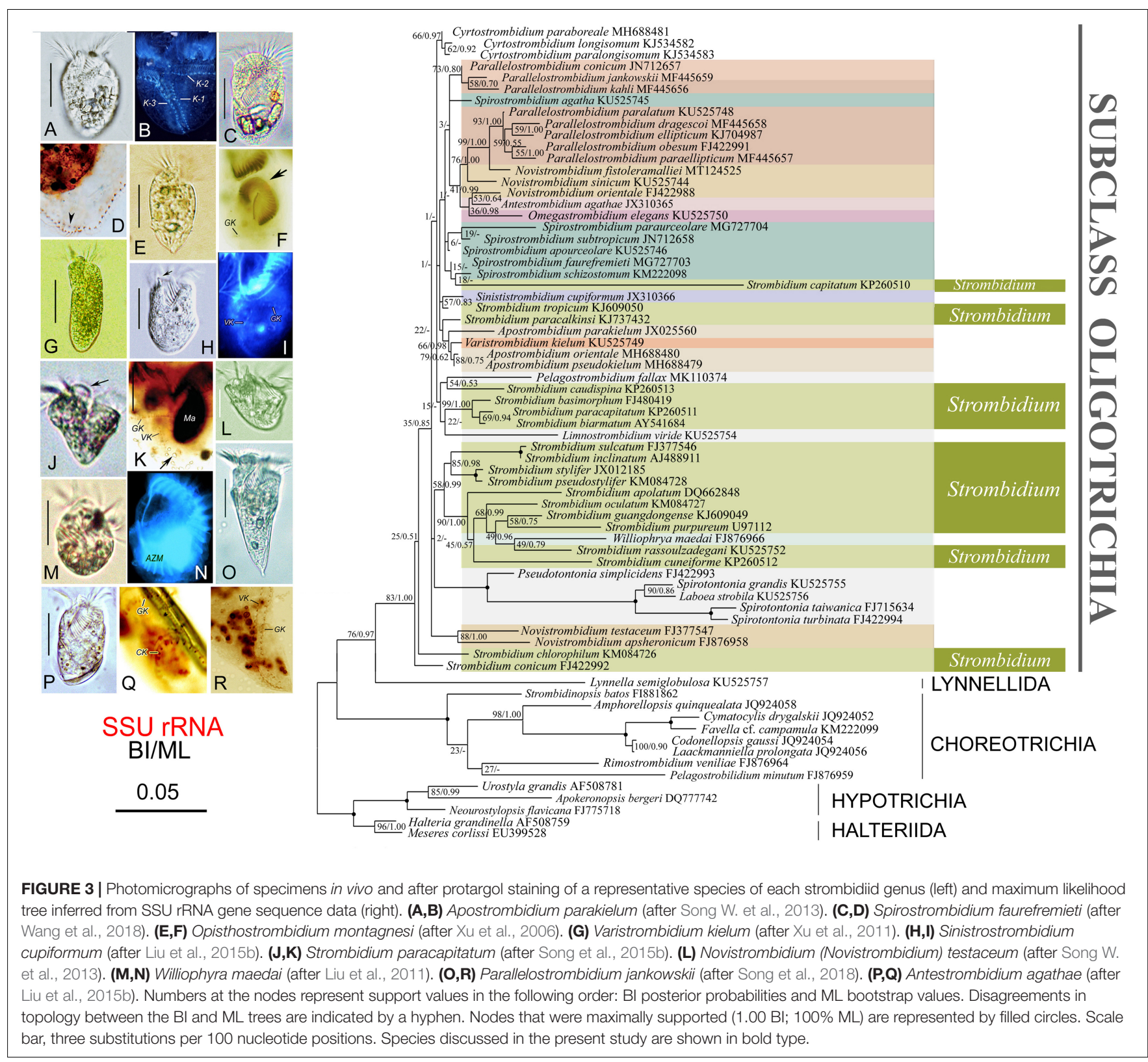

and revealed its ciliary pattern for the first time. Based on the girdle kinety performing a " $\Omega$ " shape, Agatha (2004) established the genus Omegastrombidium and designated O. elegans the type species.

Genus Opisthostrombidium (Agatha, 2011)

Diagnosis: Strombidiidae with oral primordium anterior to the horizontal girdle kinety and associated extrusome attachment sites (Agatha, 2011).

Type species: Opisthostrombidium montagnesi (Xu et al., 2006; Agatha, 2011)

In some Strombidium species, the oral primordium forms anteriorly to the horizontal girdle kinety and extrusome attachment sites, thus differing from the usual arrangement in Strombidium species in which the oral primordium forms posteriorly to the horizontal girdle kinety and extrusome attachment sites. The genus Opisthostrombidium is separated from Strombidium based on this character.

Genus: Parallelostrombidium (Agatha, 2004)

Diagnosis: Ventral kinety follows the posterior portion of the dextrally spiraled girdle kinety; thus, both kineties have the same orientation (Agatha, 2004).

Type species: Parallelostrombidium rhyticollare (Corliss and Snyder, 1986; Agatha, 2004)

Corliss and Snyder (1986) described this species under the name Strombidium rhyticollare. Petz et al. (1995) provided a redescription and transferred it to the genus Spirostrombidium based on the spiraled girdle kinety. Later, based on the similar orientation of the ventral and girdle kineties, Agatha (2004) 
established the genus Parallelostrombidium and designated P. rhyticollare as the type species. Agatha (2004) concluded that the ventral kinety and the posterior portion of the girdle kinety in Parallelostrombidium may or may not be inversely oriented.

Genus Sinistrostrombidium (Liu et al., 2015b)

Diagnosis: Strombidiidae with a ventral kinety and sinistrally spiraled girdle kinety; oral primordium develops below left end of girdle kinety.

Type species: Sinistrostrombidium cupiformum (Liu et al., 2015b)

In strombidiids, the girdle kinety is generally circular or dextrally spiraled. In S. cupiformum, however, the girdle kinety is sinistrally spiraled, based on which the genus Sinistrostrombidium was established (Liu et al., 2015b).

Genus: Spirostrombidium (Jankowski, 1978)

Diagnosis: Girdle kinety dextrally spiraled, posterior portion inversely orientated and parallel to longitudinal ventral kinety (Agatha, 2004).

Type species: Spirostrombidium sauerbreyae (Kahl, 1932)

The genus Spirostrombidium was established by Jankowski (1978) and redefined by Agatha (2004). The ciliary pattern of this genus is similar to that of Parallelostrombidium except that the posterior portions of the ventral kinety and girdle kinety have opposite orientations. A key to the identification of species of Spirostrombidium was provided by Wang et al. (2018).

Genus Strombidium (Claparède and Lachmann, 1859)

Diagnosis: Girdle kinety horizontal. Ventral kinety longitudinal, occasionally reduced, or lacking. Oral primordium develops at or below level of girdle kinety (Agatha, 2004).

Type species: Strombidium sulcatum (Claparède and Lachmann, 1859)

Strombidium is the type and the most speciose genus in the family Strombidiidae; however, some poorly characterized nominal species have been misidentified as Strombidium.

Genus Varistrombidium (Xu et al., 2011)

Diagnosis: Strombidiidae with five spirally arranged somatic kineties that run obliquely across the ventral side and parallel to each other, with the longest two extending onto the dorsal side and terminating in the caudal area (Xu et al., 2011).

Type species: Varistrombidium kielum (Maeda and Carey, 1985; Xu et al., 2011)

Kahl (1932) described a species collected from marine sand in Kiel Bay, Germany, and identified it as an unknown species of Strombidium. Maeda and Carey (1985) named the form Strombidium kielum. Xu et al. (2011) redescribed this species and revealed its unique ciliary pattern, based on which they established the genus Varistrombidium.

Genus Williophrya (Liu et al., 2011)

Diagnosis: Strombidiidae with undifferentiated adoral membranelles; somatic ciliature consisting of only a single-rowed girdle kinety that is horizontally oriented and bipartite.

Type species: Williophrya maedai (Liu et al., 2011)

Williophrya maedai is the only species in the family Strombidiidae with undifferentiated adoral membranelles. Based on this character, Liu et al. (2011) established the genus Williophrya.

\section{Key to the Identification of Genera in the Family Strombidiidae}

For the identification of each genus, detailed information on the somatic ciliary pattern, and for some genera the position of the oral primordium, is necessary.

1 Adoral zone of membranelles divided into collar and ventral

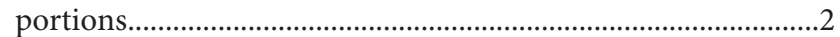
$1^{\prime}$ Adoral zone of membranelles undivided..............Williophyra

2 One to three somatic kineties..........................................................

$2^{\prime}$ More than three somatic kineties.............................................11

3 Girdle kinety horizontally oriented...............................................

$3^{\prime}$ Girdle kinety not horizontally oriented.....................................

4 Oral primordium located below girdle kinety

$4^{\prime}$ Oral primordium located above girdle kinety........................5

5 Oral primordium located below extrusomes..........Foissneridium

$5^{\prime}$ Oral primordium above extrusomes......Opisthostrombidium

6 Girdle kinety " $\Omega$ " shape.................................. Omegastrombidium

6' Girdle kinety not " $\Omega$ " shape.......................................................

7 Girdle kinety sinistrally spiraled.......................inistrostrombidium

$7^{\prime}$ Girdle kinety dextrally spiraled.................................................

8 With circular kinety..............................................Antestrombidium

$8^{\prime}$ Without circular kinety................................................................

9 Ventral kinety perpendicular to posterior portion of girdle kinety................................................................Novistrombidium

$9^{\prime}$ Ventral kinety not perpendicular to posterior portion of girdle kinety. . .10

10 Ventral kinety parallel with girdle kinety.

Parallelostrombidium

$10^{\prime}$ Ventral kinety inversely parallel with girdle kinety.....

................................................................Spirostrombidium

11 Five obliquely oriented kineties on ventral side.

Varistrombidium

$11^{\prime}$ Two longitudinally oriented kineties on ventral side.

Apostrombidium

\section{Phylogeny of Strombidiid Genera Based on SSU rRNA Gene Sequences}

The tree topologies from the BI and ML analyses are similar; therefore, only the ML tree is presented with support values from both methods at the branch nodes (Figure 3). DNA sequences have been reported for 10 of the 12 genera in the family Strombidiidae, the exceptions being Foissneridium and Opisthostrombidium.

Each of the genera Strombidium and Spirostrombidium is polyphyletic, which is consistent with previous studies (Wang et al., 2018; Song et al., 2020). To date, there is no agreed interpretation of their polyphyly. Species of Strombidium fall into several assemblages, some with morphological support: (1) Strombidium conicum and S. chlorophyllum are basal within the Oligotrichia, and their close relationship corresponds to their morphological similarity in that both species share a special kind of hemitheca; (2) Strombidium basimorphum, S. paracapitatum, and S. biarmatum form a well-supported clade which corresponds with their morphological similarity in that each has two types of extrusome whereas all other strombidiids 
have only one; (3) Strombidium apolatum, S. rassoulzadegani, S. oculatum, S. purpureum, S. guangdongense, and S. cuneiforme fall into a well-supported clade that also includes Williophrya maedai (present work; Liu et al., 2011, 2013, 2015a, 2016; Song W. et al., 2013; Song et al., 2015a,b, 2018, 2019; Wang et al., 2018). This has been referred to as the "eyespot clade" since all species within it possess a pigment spot, although $S$. purpureum lacks detailed in vivo information (Gao et al., 2016; Liu et al., 2016). Spirostrombidium is polyphyletic, although the positions of some Spirostrombidium species are not stable and have only low statistical support, which is consistent with previous studies (Wang et al., 2018; Song et al., 2020).

The genus Parallelostrombidium forms two clusters that correspond to differences in cell shape and somatic ciliary pattern, which is consistent with previous phylogenetic studies (Liu et al., 2013, 2015a; Song et al., 2018). One cluster comprises Parallelostrombidium conicum, P. jankowskii, and P. kahli, each of which has an obconical cell shape with a pointed posterior end and their ventral kinety parallel to the girdle kinety except the anteriormost portion. The other cluster comprises five species that share a dorsoventrally flattened cell shape with a rounded posterior end, and only the posterior portion of the ventral kinety is parallel to the girdle kinety.

Species of Novistrombidium are divided into two distantly related assemblages, which corresponds with the separation of this genus into two subgenera and may support their raising to genus rank (Agatha and Strüder-Kypke, 2014; Küppers et al., 2019). The subgenus Novistrombidium (Novistrombidium) is monophyletic whereas the subgenus Novistrombidium (Propecingulum) is not monophyletic as each of its species clusters with other genera.

The three Apostrombidium species and V. kielum form a clade (Figure 3), and previous studies have consistently recovered a close relationship between Apostrombidium and Varistrombidium (Liu et al., 2013, 2016; Song W. et al., 2013; Song et al., 2015a, 2019; Tsai et al., 2015). Morphological data support this finding since both genera have a dorsal split of the girdle kinety and long cilia on the dorsal side (Gao et al., 2016).

In the BI tree (not shown), Antestrombidium agathae clusters with Omegastrombidium elegans and then clusters with Novistrombidium orientale, whereas in the ML tree A. agathae clusters with $N$. orientale, which together cluster with Omegastrombidium elegans. In several previous studies, A. agathae clusters with O. elegans (Liu et al., 2015b, 2016; Gao et al., 2016; Song et al., 2019). This finding supports the close evolutionary relationship between Antestrombidium and Omegastrombidium hypothesized in Liu et al. (2015b) and corresponds with the similarity of their morphology. For example, the circular kinety of Antestrombidium appears to be homologous to the $\Omega$-shaped girdle kinety in Omegastrombidium.

Sinistrostrombidium cupiformum clusters with Strombidium tropicum, which is consistent with previous studies (Liu et al., 2015b; Wang et al., 2018; Song et al., 2019). It is noteworthy that the girdle kinety of Strombidium tropicum is slightly spiraled, i.e., the left end of the girdle kinety is positioned higher than the right one, and may represent a ciliary pattern from which
Sinistrostrombidium originated (Liu et al., 2015a,b). Nevertheless, the evolutionary relationship between these two species requires further investigation since previous studies have reported that Sinistrostrombidium cupiformum forms an isolated basal branch in some phylogenetic tress (Gao et al., 2016; Liu et al., 2016).

\section{Geographic Distribution of the Strombidiids in China}

Eleven of the 12 genera of the family Strombidiidae have been found in Chinese coastal waters (Figures 1, 4), the exception being Foissneridium which has so far only been isolated from the Barents Sea (Meunier, 1910). In terms of species numbers, the genus Strombidium is best represented with 21 species (Figure 4A). This is consistent with findings in other geographic regions such as the northwest and south Atlantic Ocean, the Baltic Sea, and the Mediterranean Sea, where Strombidium is also the strombidiid genus represented by the largest number of species (Dolan and Marrasé, 1995; Santoferrara and Alder, 2009; Agatha, 2011). Ranking second and third are Spirostrombidium (nine species) and Parallelostrombidium (eight species), respectively (Figure 4A). For Varistrombidium,

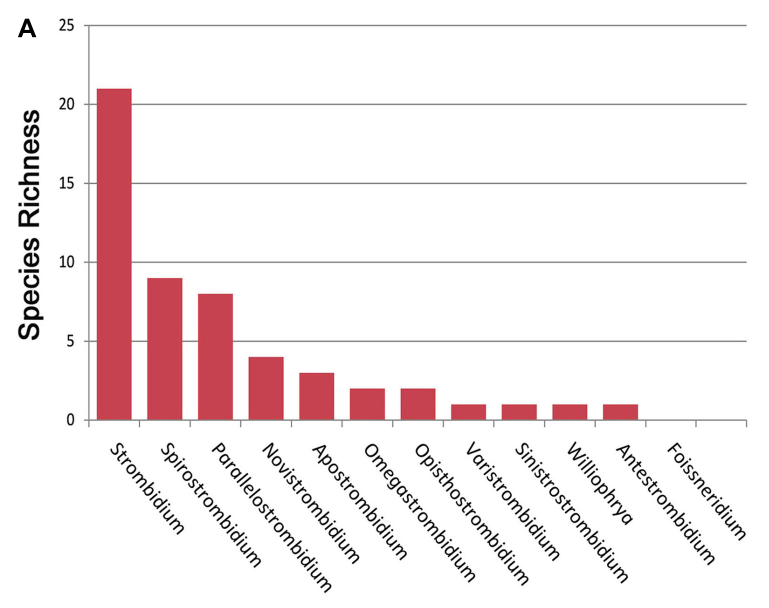

B

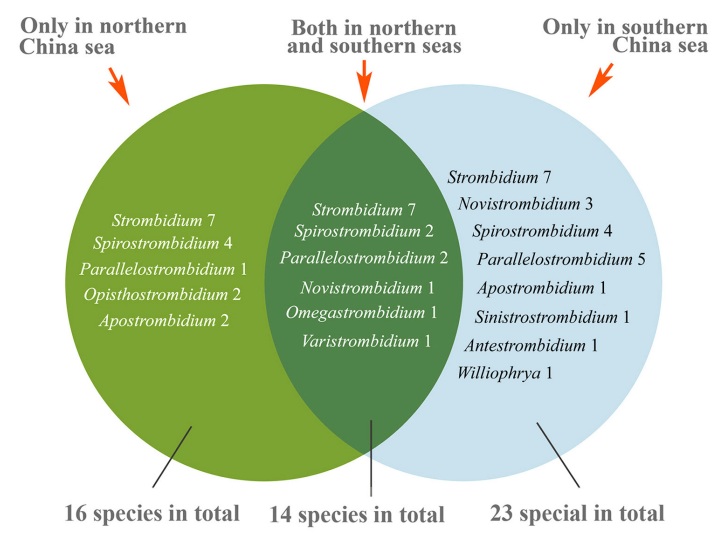

FIGURE 4 | Diversity of strombidiids collected from China (A) Species richness of each genus. (B) Comparison of species composition between coastal waters of northern and southern China. 


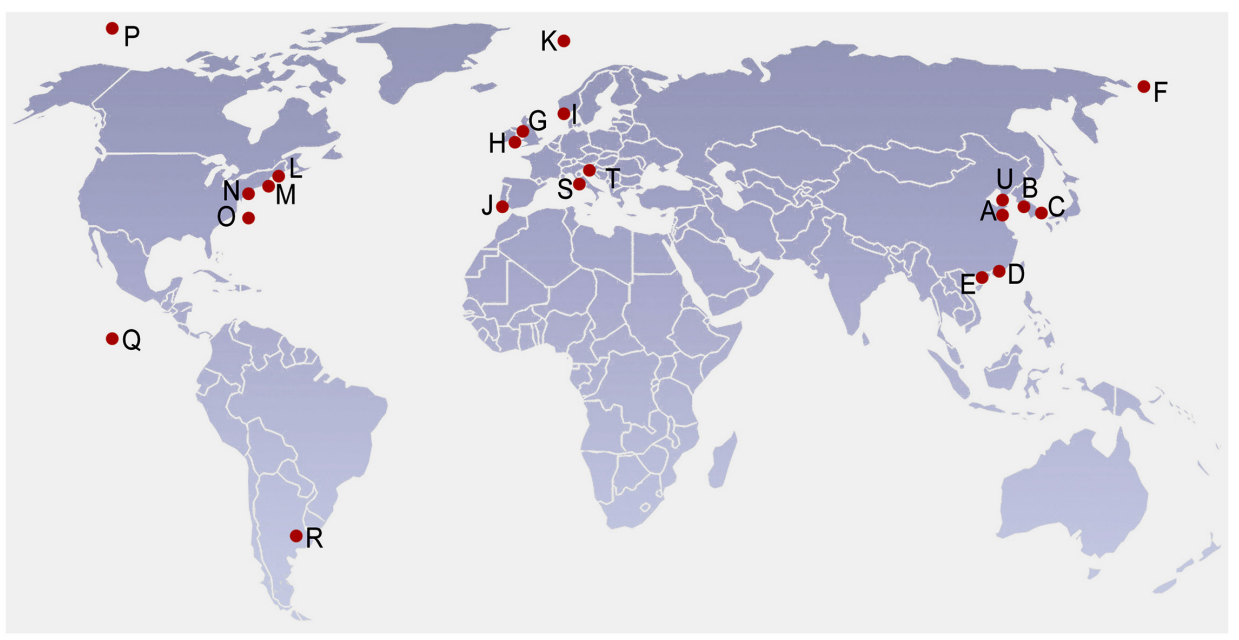

A Qingdao, China

B West of Korea

C South of Korea

D Zhujiang, China

E Zhanjiang, China

$F$ Bering Sea

G Isle of Man, Irish Sea

H Dublin Bay, Irish Sea

I Framvaren Fjord

$\mathrm{J}$ the Ria Formosa National Park, Faro

K Kongsfjorden, Svalbard

L Maine

M Cape Cod, Mass

$\mathrm{N}$ Long island sound

O Gulf Stream

P Arctic Ocean

Q East Pacific Rise

R Buenos Aires

ABCDEFGHIJKLMNOPQR STU ABCDEFGHIJKLMNOPQRSTU

$S$ Leghorn, Italy
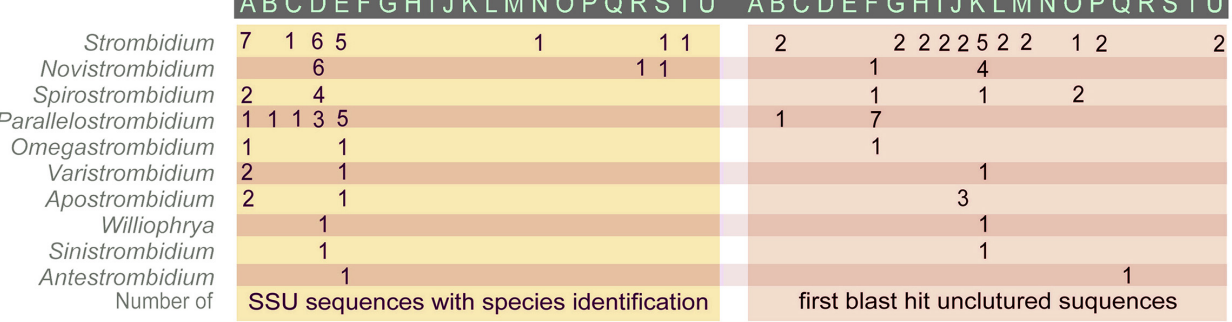

$T$ Gulf of Trieste

U Yantai, China

FIGURE 5 | Global geographic distribution of the 12 genera of Strombidiidae based on SSU sequences.

Williophrya, Sinistrostrombidium, and Antestrombidium, only one species each has been recorded in Chinese coastal waters. Regarding the distribution of these genera, Strombidium has a most extensive range with occurrences at 15 sites, followed by Parallelostrombidium (10 sites) and Spirostrombidium (nine sites) (Figure 1B). The comparison of diversity in these sites showed that the highest species richness (14 species) occurred at site $\mathrm{k}$ and the lowest was at five sites (h, i, l, n, p) with only one species at each (Figure 1C). At the genus level, sites a, $\mathrm{k}$, and $\mathrm{q}$ were the most genus-rich with six genera at each whereas sites $d, h, i, l, n$, and $\mathrm{p}$ each had only one genus (Figure 1B).

Occurrences of strombidiids in northern and southern China were compared (Figure 4B). Representative of seven genera, i.e., Strombidium, Spirostrombidium, Parallelostrombidium, Novistrombidium, Omegastrombidium, Apostrombidium, and Varistrombidium, were found both in northern and southern China. Opisthostrombidium has only been reported from northern Chinese coastal waters, while Williophrya, Sinistrostrombidium, and Antestrombidium have only been reported from southern Chinese coastal waters. The total number of strombidiids is higher in southern China where 37 species representing 10 genera were collected compared to 30 species and eight genera in northern China. There are two possible reasons for this: (1) the sampling area was wider and the number of sampling sites was higher in southern than in northern China; (2) the environment features of some southern coastal habitats are more suitable for ciliates than those in the north. For example, mangrove wetlands, which are nutrient-rich and could provide a greater quantity and diversity of food resources for ciliates, are only located in southern China.

\section{Global Distribution of the Strombidiids Based on Molecular Information}

Most Strombidiidae species for which gene sequence data (mostly SSU rRNA but also ITS and LSU rRNA sequences of some taxa) are available in the GenBank database are from specimens collected from coastal water habitats, including sediments, lagoons, and bays, which are much easier to sample than oceanic habitats. To infer the possible worldwide distribution of the reported species within Strombidiidae, BLAST comparisons against the GenBank Nucleotide collection database were run with SSU rRNA gene sequences of known species. The Sequence Read Archive (SRA) contains only short sequences from high throughput sequencing and thus was not used in the present study.

The nearest environmental neighbor (NEN) for each species, i.e., the environmental sequence with the highest sequence similarity, was obtained as the first BLAST hit. The NENs of strombidiids were from various habitats including mangroves, coastal waters, estuaries, fjords, solar saltern ponds, open ocean waters, and oxygen-depleted marine environments (Figure 5 and Table 1). Parallelostrombidium conicum was identical to its NEN (100\% similarity), 
TABLE 1 | Locations of SSU rRNA gene sequences and their nearest environmental neighbor (NEN).

\begin{tabular}{|c|c|c|c|c|c|}
\hline Species name & Location & $\begin{array}{c}\text { GenBank } \\
\text { No. }\end{array}$ & $\begin{array}{l}\text { Similarity } \\
\text { (NEN) }\end{array}$ & $\begin{array}{l}\text { GenBank } \\
\text { No. (NEN) }\end{array}$ & $\begin{array}{l}\text { Location } \\
\text { (NEN) }\end{array}$ \\
\hline $\begin{array}{l}\text { Antestrombidium } \\
\text { agathae }\end{array}$ & $E$ & JX310365 & 98.03 & KJ757606 & Q \\
\hline $\begin{array}{l}\text { Apostrombidium } \\
\text { pseudokielum }\end{array}$ & A & MH688479 & 99.34 & EU371386 & K \\
\hline $\begin{array}{l}\text { Apostrombidium } \\
\text { parakielum }\end{array}$ & A & JX025560 & 97.92 & EU371386 & K \\
\hline $\begin{array}{l}\text { Apostrombidium } \\
\text { orientale }\end{array}$ & $E$ & MH688480 & 99.24 & EU371386 & K \\
\hline $\begin{array}{l}\text { Novistrombidium } \\
\text { apsheronicum }\end{array}$ & $\mathrm{D}$ & FJ876958 & 95.89 & EU371386 & $\mathrm{K}$ \\
\hline $\begin{array}{l}\text { Novistrombidium } \\
\text { orientale }\end{array}$ & $\mathrm{D}$ & FJ422988 & 97.97 & EU371386 & K \\
\hline $\begin{array}{l}\text { Novistrombidium } \\
\text { sinicum }\end{array}$ & $\mathrm{D}$ & FJ422989 & 98.03 & EU371386 & K \\
\hline $\begin{array}{l}\text { Novistrombidium } \\
\text { sinicum }\end{array}$ & $\mathrm{D}$ & KU525744 & 98.01 & EU371386 & K \\
\hline $\begin{array}{l}\text { Novistrombidium } \\
\text { sinicum }\end{array}$ & $\mathrm{D}$ & FJ422990 & 98.03 & EU371386 & K \\
\hline $\begin{array}{l}\text { Novistrombidium } \\
\text { testaceum }\end{array}$ & $\mathrm{D}$ & FJ377547 & 96.51 & EU371386 & K \\
\hline $\begin{array}{l}\text { Novistrombidium } \\
\text { testaceum }\end{array}$ & $S$ & AJ488910 & 96.95 & EU371386 & K \\
\hline $\begin{array}{l}\text { Novistrombidium } \\
\text { fistoleramalliei }\end{array}$ & $\mathrm{R}$ & MT124525 & 97.61 & KC771186 & $\mathrm{F}$ \\
\hline $\begin{array}{l}\text { Omegastrombidium } \\
\text { elegans }\end{array}$ & A & EF486862 & 96.71 & KC771186 & $\mathrm{F}$ \\
\hline $\begin{array}{l}\text { Omegastrombidium } \\
\text { elegans }\end{array}$ & $E$ & KU525750 & 97 & KC771186 & $\mathrm{F}$ \\
\hline $\begin{array}{l}\text { Parallelostrombidium } \\
\text { conicum }\end{array}$ & $E$ & JN712657 & 100 & KC771186 & $\mathrm{F}$ \\
\hline $\begin{array}{l}\text { Parallelostrombidium } \\
\text { dragescoi }\end{array}$ & $E$ & MF445658 & 96.82 & KC771186 & $\mathrm{F}$ \\
\hline $\begin{array}{l}\text { Parallelostrombidium } \\
\text { ellipticum }\end{array}$ & $\mathrm{D}$ & KJ704987 & 96.84 & KC771186 & $\mathrm{F}$ \\
\hline $\begin{array}{l}\text { Parallelostrombidium } \\
\text { jankowskii }\end{array}$ & $E$ & MF445659 & 99 & KC771186 & $\mathrm{F}$ \\
\hline $\begin{array}{l}\text { Parallelostrombidium } \\
\text { kahli }\end{array}$ & A & MF445656 & 99 & KC771186 & $\mathrm{F}$ \\
\hline $\begin{array}{l}\text { Parallelostrombidium } \\
\text { obesum }\end{array}$ & $E$ & KU525733 & 90.3 & FJ032675 & B \\
\hline $\begin{array}{l}\text { Parallelostrombidium } \\
\text { obesum }\end{array}$ & $\mathrm{D}$ & FJ422991 & 97.24 & KC771186 & $\mathrm{F}$ \\
\hline $\begin{array}{l}\text { Parallelostrombidium } \\
\text { paraellipticum }\end{array}$ & $\mathrm{D}$ & MF445657 & 96.74 & KC771186 & $\mathrm{F}$ \\
\hline $\begin{array}{l}\text { Parallelostrombidium } \\
\text { paralatum }\end{array}$ & $E$ & KU525748 & 97.8 & KC771186 & $\mathrm{F}$ \\
\hline $\begin{array}{l}\text { Parallelostrombidium } \\
\text { paralatum }\end{array}$ & $\mathrm{B}$ & KF800042 & 96.67 & KC771186 & $\mathrm{F}$ \\
\hline $\begin{array}{l}\text { Parallelostrombidium } \\
\text { paralatum }\end{array}$ & $\mathrm{C}$ & HM140404 & 96.84 & KC771186 & $\mathrm{F}$ \\
\hline $\begin{array}{l}\text { Sinistrostrombidium } \\
\text { cupiformum }\end{array}$ & $\mathrm{D}$ & JX310366 & 98.84 & EU371386 & $\mathrm{K}$ \\
\hline $\begin{array}{l}\text { Spirostrombidium } \\
\text { subtropicum }\end{array}$ & $E$ & JN712658 & 98.72 & EU371386 & $\mathrm{K}$ \\
\hline $\begin{array}{l}\text { Spirostrombidium } \\
\text { apourceolare }\end{array}$ & E & KU525746 & 99.52 & KJ760066 & O \\
\hline
\end{tabular}

(Continued)
TABLE 1 | Continued

\begin{tabular}{|c|c|c|c|c|c|}
\hline Species name & Location & $\begin{array}{l}\text { GenBank } \\
\text { No. }\end{array}$ & $\begin{array}{l}\text { Similarity } \\
\text { (NEN) }\end{array}$ & $\begin{array}{l}\text { GenBank } \\
\text { No. (NEN) }\end{array}$ & $\begin{array}{l}\text { Location } \\
\text { (NEN) }\end{array}$ \\
\hline $\begin{array}{l}\text { Spirostrombidium } \\
\text { agathae }\end{array}$ & A & KU525745 & 98.63 & KJ760066 & $\mathrm{O}$ \\
\hline $\begin{array}{l}\text { Spirostrombidium } \\
\text { schizostomum }\end{array}$ & $\mathrm{D}$ & KM222098 & 96.44 & KC771186 & $\mathrm{F}$ \\
\hline $\begin{array}{l}\text { Spirostrombidium } \\
\text { faurefremieti }\end{array}$ & A & MG727703 & 99.4 & EU371386 & K \\
\hline $\begin{array}{l}\text { Spirostrombidium } \\
\text { paraurceolare }\end{array}$ & E & MG727704 & 96.44 & EU371386 & K \\
\hline Strombidium apolatum & A & DQ662848 & 99.71 & GU206560 & $\mathrm{G}, \mathrm{H}, \mathrm{L}$ \\
\hline $\begin{array}{l}\text { Strombidium } \\
\text { biarmatum }\end{array}$ & $\mathrm{T}$ & AY541684 & 99.78 & KJ761932 & P \\
\hline $\begin{array}{l}\text { Strombidium } \\
\text { basimorphum }\end{array}$ & $\mathrm{D}$ & FJ480419 & 98.65 & EF527106 & 1 \\
\hline $\begin{array}{l}\text { Strombidium } \\
\text { rassoulzadegani }\end{array}$ & $\mathrm{N}$ & AY257125 & 99.94 & AY180033 & M \\
\hline $\begin{array}{l}\text { Strombidium } \\
\text { rassoulzadegani }\end{array}$ & A & KU525752 & 98.55 & AY180033 & M \\
\hline Strombidium capitatum & A & KP260510 & 98.17 & JX178772 & $U$ \\
\hline $\begin{array}{l}\text { Strombidium } \\
\text { caudispina }\end{array}$ & E & KP260513 & 99.87 & KJ759113 & $\mathrm{P}$ \\
\hline $\begin{array}{l}\text { Strombidium } \\
\text { chlorophilum }\end{array}$ & A & KM084726 & 96.96 & KJ760066 & $\mathrm{O}$ \\
\hline Strombidium conicum & $\mathrm{D}$ & FJ422992 & 97.81 & EU371386 & $\mathrm{K}$ \\
\hline $\begin{array}{l}\text { Strombidium } \\
\text { cuneiforme }\end{array}$ & E & KP260512 & 96.95 & GU206562 & G \\
\hline $\begin{array}{l}\text { Strombidium } \\
\text { guangdongense }\end{array}$ & E & KJ609049 & 99.2 & KR028987 & J \\
\hline $\begin{array}{l}\text { Strombidium } \\
\text { intermedium }\end{array}$ & A & $\mathrm{KX} 131153$ & 95.61 & AY180033 & M \\
\hline Strombidium inclinatum & S & AJ488911 & 96.38 & EU371386 & $\mathrm{K}$ \\
\hline Strombidium oculatum & D & KM084727 & 97.67 & GU206561 & $\mathrm{H}$ \\
\hline $\begin{array}{l}\text { Strombidium } \\
\text { paracapitatum }\end{array}$ & D & KP260511 & 99.04 & EF527106 & 1 \\
\hline $\begin{array}{l}\text { Strombidium } \\
\text { paracalkinsi }\end{array}$ & C & KJ737432 & 99.04 & EU371386 & $\mathrm{K}$ \\
\hline $\begin{array}{l}\text { Strombidium } \\
\text { pseudostylifer }\end{array}$ & E & KM084728 & 98.92 & FJ543106 & $\mathrm{B}$ \\
\hline Strombidium stylifer & $\mathrm{D}$ & JX012185 & 99.49 & FJ543106 & $\mathrm{B}$ \\
\hline Strombidium stylifer & $A$ & DQ631805 & 99.55 & FJ543106 & $\mathrm{B}$ \\
\hline Strombidium sulcatum & A & FJ377546 & 96.23 & EU371386 & K \\
\hline Strombidium sulcatum & A & DQ777745 & 96.45 & EU371386 & K \\
\hline Strombidium triquetrum & $E$ & KJ609052 & 99.71 & JX178772 & $U$ \\
\hline Strombidium tropicum & $\mathrm{D}$ & KJ609050 & 99.54 & EU371386 & $\mathrm{K}$ \\
\hline Varistrombidium kielum & $E$ & KJ609051 & 97.8 & EU371386 & K \\
\hline Varistrombidium kielum & A & KU525749 & 98.97 & EU371386 & K \\
\hline Varistrombidium kielum & A & DQ811090 & 98.31 & EU371386 & K \\
\hline Williophrya maedai & $\mathrm{D}$ & FJ876966 & 95.32 & KR028987 & $J$ \\
\hline
\end{tabular}

For explanation of locations, see Figure 5.

which was reported from the Bering Sea (KC771186). Five Strombidium species, four Novistrombidium species, three Apostrombidium species, three Spirostrombidium species, Sinistrostrombidium cupiformum, and Varistrombidium kielum each had the same NEN, i.e., EU371386, which was 
collected from Kongsfjorden, Svalbard (Table 1). Similarly, seven out of eight Parallelostrombidium species, Omegastrombidium elegans, Spirostrombidium schizostomum, and Novistrombidium fistoleramalliei also had the same NEN, i.e., KC771186, which was collected from the Bering Sea. The NENs of Strombidium rassoulzadegani and $S$. intermedium, and of S. basimorphum and $S$. paracapitatum, were collected from an oxygen-depleted salt marsh in Massachusetts, United States (AY180033) and the anoxic Framvaren fjord in Norway (EF527106), respectively.

For environmental sequencing studies, delineating operational taxonomic units (OTUs) is a key step in the analysis and can significantly affect the results (Nebel et al., 2011). A 5\% cutoff ( $95 \%$ sequence similarity) was recommended for microbial eukaryotes by Caron et al. (2009). For ciliates, a 1\%-3\% cutoff value (i.e., 97-99\% sequence similarity) for the SSU rRNA gene is often used (Stoeck et al., 2006; Doherty et al., 2007, 2010; Sun et al., 2017,2019), although a finer $(<1 \%)$ cutoff might be needed for some groups (Xu et al., 2013). In the present analysis, the average similarity of the 49 species/populations of strombidiids was $97.9 \%$ with their NENs, ranging from 90.3 to $100 \%$. Among these, 17 species/populations had a similarity with their NEN of $>99 \%, 15$ had a similarity of $97-99 \%, 16$ had a similarity of $95-97 \%$, and one had a similarity of $90.3 \%$. If a $97 \%$ similarity cutoff is used to distinguish different species, $65 \%$ of the 49 species/populations are conspecific with their NEN. Even if a much stricter cutoff is used (1\%), 35\% of the species/populations are conspecific with their NEN. These findings suggest that the species isolated from Chinese coastal waters were likely to be globally distributed based on the $5 \%$ cutoff suggested by Caron et al. (2009) with 48 out of 49 species being conspecific with their NEN. Furthermore, it is noteworthy that some species from different genera can have the same NEN, which may indicate that the environmental sampling and sequencing efforts are far from saturation. Increased collection of ciliate environmental sequences from different marine environments, especially those that are difficult to sample, will help improve knowledge and

\section{REFERENCES}

Agatha, S. (2004). Evolution of ciliary patterns in the Oligotrichida (Ciliophora, Spirotricha) and its taxonomic implications. Zoology 107, 153-168. doi: 10. 1016/j.zool.2004.02.003

Agatha, S. (2011). Updated hypothesis on the evolution of oligotrichid ciliates (Ciliophora, Spirotricha, Oligotrichida) based on somatic ciliary patterns and ontogenetic data. Eur. J. Protistol. 47, 51-56. doi: 10.1016/j.ejop.2010. 09.001

Agatha, S. (2014). Redescription of Strombidium coronatum (Leegaard, 1915) Kahl, 1932 (Ciliophora, Spirotricha) based on live observation, protargol impregnation, and scanning electron microscopy. Acta Protozool. 53, 287-294. doi: 10.4467/16890027AP.14.026.2021

Agatha, S., and Strüder-Kypke, M. C. (2014). What morphology and molecules tell us about the evolution of Oligotrichea (Alveolata, Ciliophora). Acta Protozool. 53, 77-90. doi: 10.4467/16890027AP.14.008.1445

Azam, F., Fenchel, T., Field, J. G., Gray, J. S., Meyer-Reil, L. A., and Thingstad, F. (1983). The ecological role of water-column microbes in the sea. Mar. Ecol. Prog. Ser. 10, 257-263. doi: 10.3354/meps01 0257

Azam, F., and Malfatti, F. (2007). Microbial structuring of marine ecosystems. Nat. Rev. Microbiol. 5, 782-791. doi: 10.1038/nrmicro1798 understanding of the biogeographical distribution patterns of marine strombidiids. Also, the enrichment of the full-length or near full-length SSU rRNA gene sequences from various oceanic environments paired with detailed morphological observations will serve to improve the database, thereby contributing to the identification of environmental sequences.

\section{DATA AVAILABILITY STATEMENT}

The original contributions presented in the study are included in the article/supplementary material, further inquiries can be directed to the corresponding author/s.

\section{AUTHOR CONTRIBUTIONS}

LL, WeiS, and MS conceived the research. WenS, DX, and XC conducted the analysis and drafted the manuscript. AW critically reviewed the findings and improved the manuscript. All authors contributed to the article and approved the submitted version.

\section{FUNDING}

This work was supported by the National Natural Science Foundation of China (project numbers: 31772431 and 31801955) and the National Research Foundation of Korean Government of MOE and MSIP (2016H1D3A1062066, 2018R1A2B6007973, and 2021R1I1A2048744).

\section{ACKNOWLEDGMENTS}

We would like to thank Weiwei Liu from the Chinese Academy of Sciences for his help.

Bai, Y., Wang, R., Liu, W. W., Warren, A., Zhao, Y., and Hu, X. Z. (2020a). Redescriptions of three tintinnine ciliates (Ciliophora: Tintinnina) from coastal waters in China based on lorica features, cell morphology, and rDNA sequence data. Eur. J. Protistol. 72:125659. doi: 10.1016/j.ejop.2019.1 25659

Bai, Y., Wang, R., Song, W., Suzuki, T., and Hu, X. Z. (2020b). Redescription of five tintinnine ciliates (Alveolata: Ciliophora: Oligotrichea) from coastal waters of Qingdao, China. Mar. Life Sci. Technol. 2, 209-221. doi: 10.1007/s42995-02000034-2

Caron, D. A., Countway, P. D., Savai, P., Gast, R. J., Schnetzer, A., Moorthi, S. D., et al. (2009). Defining DNA-based operational taxonomic units for microbialeukaryote ecology. Appl. Environ. Microbiol. 75, 5797-5808. doi: 10.1128/AEM. 00298-09

Corliss, J. O., and Snyder, R. A. (1986). A preliminary description of several new ciliates from the Antarctica, including Cohnilembus grassei n. sp. Protistologica 22, 39-46.

de Vargas, C., Audic, S., Henry, N., Decelle, J., Mahé, F., Logares, R., et al. (2015). Eukaryotic plankton diversity in the sunlit ocean. Science 348:1261605. doi: 10.1126/science. 1261605

Doherty, M., Costas, B., McManus, G., and Katz, L. (2007). Culture-independent assessment of planktonic ciliates in coastal northwest Atlantic waters. Aquat. Microb. Ecol. 48, 141-154. doi: 10.3354/ame048141 
Doherty, M., Tamura, M., Costas, B. A., Ritchie, M. E., McManus, G. B., and Katz, L. A. (2010). Ciliate diversity and distribution across an environmental and depth gradient in Long Island Sound, USA. Environ. Microbiol. 12, 886-898. doi: 10.1111/j.1462-2920.2009.02133.x

Dolan, J. R., and Marrasé, C. (1995). Planktonic ciliate distribution relative to a deep chlorophyll maximum: Catalan Sea, N.W. Mediterranean, June 1993. Deep Sea Res. Part I 42, 1965-1987. doi: 10.1016/0967-0637(95)00092-5

Dolan, J. R., Montagnes, D. J. S., Agatha, S., Coats, D. W., and Stoecker, D. K. (2013). The Biology and Ecology of Tintinnid Ciliates: Models for Marine Plankton. Chichester: John Wiley, 296. doi: 10.1086/682633

Fenchel, T. (2008). The microbial loop-25 years later. J. Exp. Mar. Biol. Ecol. 366, 99-103. doi: 10.1016/j.jembe.2008.07.013

Florentin, R. (1901). Description de deux infusoires ciliés nouveaux des mares salées de Lorraine suivie de quelques considerations. Annls. Sci. Nat. (Zool.) Paléontol. 12, 343-363.

Foissner, W., Chao, A., and Katz, L. A. (2008). Diversity and geographic distribution of ciliates (Protista: Ciliophora). Biodivers. Conserv. 17, 345-363. doi: 10.1007/978-90-481-2801-3_9

Gao, F., Huang, J., Zhao, Y., Li, L., Liu, W., Miao, M., et al. (2017). Systematic studies on ciliates (Alveolata, Ciliophora) in China: progress and achievements based on molecular information. Eur. J. Protistol. 61, 409-423. doi: 10.1016/j. ejop.2017.04.009

Gao, F., Li, J., Song, W., Xu, D., Warren, A., Yi, Z., et al. (2016). Multi-gene-based phylogenetic analysis of oligotrich ciliates with emphasis on two dominant groups: cyrtostrombidiids and strombidiids (Protozoa, Ciliophora). Mol. Phylogenet. Evol. 105, 241-250. doi: 10.1016/j.ympev.2016. 08.019

Grattepanche, J., Santoferrara, L. F., McManus, G. B., and Katz, L. (2016). Unexpected biodiversity of ciliates in marine samples from below the photic zone. Mol. Ecol. 25, 3987-4000. doi: 10.1111/mec.13745

Hall, T. A. (1999). BioEdit: a user-friendly biological sequence alignment editor and analysis program for Windows 95/98/NT. Nucleic Acids Symp. Ser. 41, 95-98. doi: 10.1021/bk-1999-0734.ch008

Hu, X. Z., Lin, X. F., and Song, W. B. (2019). Ciliate Atlas: Species Found in the South China Sea. Beijing: Science press, 1-634. doi: 10.1007/978-981-13-5901-9

Huang, H., Yang, J., Huang, S., Gu, B., Wang, Y., Wang, L., et al. (2021). Spatial distribution of planktonic ciliates in the western Pacific Ocean: along the transect from Shenzhen (China) to Pohnpei (Micronesia). Mar. Life Sci. Technol. 3, 103-115. doi: 10.1007/s42995-020-00 075-7

Jankowski, A. W. (1978). Revision of a system of class Polyhymenophora (Spirotricha). Tezisky Dokl. Zool. Inst. Akad. Nauk SSSR 1978, 39-40.

Kahl, A. (1932). "Urtiere oder Protozoa I: Wimpertiere oder Ciliata (Infusoria) 3. Spirotricha," in Die Tierwelt Deutschlands und der angrenzenden Meeresteile, 25, ed. F. Dahl (Jena: Gustav Fischer), 399-650.

Küppers, G. C., Paiva, T. S., Borges, B. N., Alfaro, E. R., and Claps, M. C. (2019). A new oligotrich (Ciliophora, Oligotrichia) from Argentina, with redefinition of Novistrombidium Song and Bradbury. Eur. J. Protistol. 69, 20-36. doi: 10.1016/ j.ejop.2019.02.006

Lee, E. S., Kim, Y. O., Agatha, S., Jung, J. H., Xu, D., and Shin, M. K. (2015). Revision of Strombidium paracalkinsi (Ciliophora: Oligotrichea: Oligotrichia), with comparison of strombidiids bearing thigmotactic membranelles. J. Eukaryot. Microbiol. 62, 400-409. doi: 10.1111/jeu.12195

Li, F., Huang, Y., Yu, Y., Liu, W., and Lin, X. (2020). Taxonomy and phylogeny of a new marine planktonic ciliate, Strombidium pseudorapulum sp. n. (Protozoa, Ciliophora, Oligotrichia). J. Ocean Univ. China 19, 954-960. doi: 10.1007/ s11802-020-4402-8

Liu, Q., Zhao, Q., McMinn, A., Yang, E. J., and Jiang, Y. (2021). Planktonic microbial eukaryotes in polar surface waters: recent advances in highthroughput sequencing. Mar. Life Sci. Technol. 3, 94-102. doi: 10.1007/s42995020-00062-y

Liu, W., Jiang, J., Xu, Y., Pan, X., Qu, Z., Luo, X., et al. (2017). Diversity of freeliving marine ciliates (Alveolata, Ciliophora): faunal studies in coastal waters of China during the years 2011-2016. Eur. J. Protistol. 61, 424-438. doi: 10.1016/j. ejop.2017.04.007

Liu, W., Shin, M. K., Yi, Z., and Tan, Y. (2021). Progress in studies on the diversity and distribution of planktonic ciliates (Protista, Ciliophora) in the South China Sea. Mar. Life Sci. Technol. 3, 28-43. doi: 10.1007/s42995-020-00070-y
Liu, W., Xu, D., Lin, X., Li, J., Gong, J., Al-Rasheid, K. A. S., et al. (2009). Novistrombidium sinicum n. sp. and Novistrombidium orientale n. sp. (Protozoa: Ciliophora): two new oligotrich ciliates from a mangrove wetland, South China. J. Eukaryot. Microbiol. 56, 459-465. doi: 10.1111/j.1550-7408. 2009.00425.x

Liu, W., Xu, D., Ma, H., Al-Farraj, S. A., Warren, A., and Yi, Z. (2016). Taxonomy and molecular systematics of three oligotrich (s.l.) ciliates including descriptions of two new species, Strombidium guangdongense sp. nov. and Strombidinopsis sinicum sp. nov. (Protozoa, Ciliophora). Syst. Biodivers. 14, 452-465. doi: 10.1080/14772000.2016.1162872

Liu, W., Yi, Z., Li, J., Warren, A., Al-Farraj, S. A., and Lin, X. (2013). Taxonomy, morphology and phylogeny of three new oligotrich ciliates (Protozoa, Ciliophora, Oligotrichia) from southern China. Int. J. Syst. Evol. Microbiol. 63, 4805-4817. doi: 10.1099/ijs.0.052878-0

Liu, W., Yi, Z., Lin, X., Li, J., Al-Farraj, A. S., Al-Rasheid, K. A. S., et al. (2015a). Morphology and molecular phylogeny of three new oligotrich ciliates (Protozoa, Ciliophora) from the South China Sea. Zool. J. Linn. Soc. 174:4. doi: 10.1111/zoj.12257

Liu, W., Yi, Z., Warren, A., Al-Rasheid, K. A. S., Al-Farraj, S. A., Lin, X., et al. (2011). Taxonomy, morphology and molecular systematics of a new oligotrich ciliate, Williophrya maedai gen. nov., sp. nov., with redescriptions of Strombidium basimorphum and Pseudotontonia simplicidens (Protozoa, Ciliophora, Oligotrichia). Syst. Biodivers. 9, 247-258. doi: 10.1080/14772000. 2011.605812

Liu, W., Yi, Z., Xu, D., Clamp, J. C., Li, J., Lin, X., et al. (2015b). Two new genera of planktonic ciliates and insights into the evolution of the family Strombidiidae (Protista, Ciliophora, Oligotrichia). PLoS One 10:e0131726. doi: 10.1371/journal.pone.0131726

Liu, W., Zhang, K., Chen, C., Li, J., Tan, Y., Warren, A., et al. (2019). Overview of the biodiversity and geographic distribution of aloricate oligotrich ciliates (Protozoa, Ciliophora, Spirotrichea) in coastal waters of southern China. Syst. Biodivers. 17, 787-800. doi: 10.1080/14772000.2019.1691081

López-García, P., Rodriguez-Valera, F., Pedros-Alio, C., and Moreira, D. (2001). Unexpected diversity of small eukaryotes in deep-sea Antarctic plankton. Nature 409, 603-607. doi: 10.1038/35054537

Lu, K., Liu, W., Warren, A., Xu, Y., Zhu, C., Zhao, Y., et al. (2020). Diversity of oligotrich ciliates (Ciliophora, Spirotrichea) in five near-shore sites along northern coast of South China Sea revealed by LSU rDNA sequences. J. Oceanol. Limnol. 38, 156-167. doi: 10.1007/s00343-019-9021-0

Lynn, D. H. (2008). The Ciliated Protozoa: Characterization, Classification, and Guide to the Literature, 3rd Edn. New York, NY: Springer, 1-605. doi: 10.1007/ 978-1-4020-8239-9

Maeda, M., and Carey, P. G. (1985). An illustrated guide to the species of the Family Strombidiidae (Oligotrichida, Ciliophora), free swimming protozoa common in the aquatic environment. Bull. Ocean Res. Inst., Univ. Tokyo 19, 1-68.

McManus, B. G., Xu, D., Costas, A. B., and Katz, A. L. (2010). Genetic identities of cryptic species in the Strombidium stylifer/apolatum/oculatum cluster, including a description of Strombidium rassoulzadegani n. sp. J. Eukaryot. Microbiol. 57, 369-378. doi: 10.1111/j.1550-7408.2010.00485.x

McManus, G. B., and Katz, L. A. (2009). Molecular and morphological methods for identifying plankton: what makes a successful marriage? J. Plankton Res. 31, 1119-1129. doi: 10.1093/plankt/fbp061

Meunier, A. (1910). Campagne Arctique de 1907. Microplankton des Mers de Barents et de Kara. Bruxelles: Bulens, i-xviii + 1-355 + Plates 1-36.

Miller, M., Pfeiffer, W., and Schwartz, T. (2010). "Creating the CIPRES Science Gateway for inference of large phylogenetic trees," in Proceedings of the Gateway Computing Environments Workshop (GCE), New Orleans, LA, 1-8. doi: 10. 1109/GCE.2010.5676129

Montagnes, D. J. S. (1996). Growth responses of planktonic ciliates in the genera Strobilidium and Strombidium. Mar. Ecol. Prog. Ser. 130, 241-254. doi: 10.3354/ meps 130241

Moon-van der Staay, S. Y., De Wachter, R., and Vaulot, D. (2001). Oceanic 18S rDNA sequences from picoplankton reveal unsuspected eukaryotic diversity. Nature 409, 607-610. doi: 10.1038/35054541

Nebel, M., Pfabel, C., Stock, A., Dunthorn, M., and Stoeck, T. (2011). Delimiting operational taxonomic units for assessing ciliate environmental diversity using small-subunit rRNA gene sequences. Environ. Microbiol. Rep. 3, 154-158. doi: $10.1111 /$ j.1758-2229.2010.00200.x 
Nylander, J. A. A. (2004). MrModeltest. Uppsala: Evolutionary Biology Centre, Uppsala University.

Penn, O., Privman, E., Ashkenazy, H., Landan, G., Graur, D., and Pupko, T. (2010a). GUIDANCE: a web server for assessing alignment confidence scores. Nucleic Acids Res. 38, W23-W28. doi: 10.1093/nar/gkq443

Penn, O., Privman, E., Landan, G., Graur, D., and Pupko, T. (2010b). An alignment confidence score capturing robustness to guide tree uncertainty. Mol. Biol. Evol. 27, 1759-1767. doi: 10.1093/molbev/msq066

Petz, W., Song, W. B., and Wilbert, N. (1995). Taxonomy and ecology of the ciliate fauna (Protozoa, Ciliophora) in the endopagial and pelagial of the Weddell Sea, Antarctica. Stapfia 40, 1-223.

Ronquist, F., and Huelsenbeck, J. P. (2003). MrBayes 3: bayesian phylogenetic inference under mixed models. Bioinformatics 19, 1572-1574. doi: 10.1093/ bioinformatics/btg180

Santoferrara, L., and Alder, V. (2009). Abundance trends and ecology of planktonic ciliates of the south-western Atlantic (35-638S): a comparison between neritic and oceanic environments. J. Plankton Res. 31, 837-851. doi: 10.1093/plankt/ fbp 033

Santoferrara, L. F., Grattepanche, J., Katz, L., and McManus, G. B. (2016). Patterns and processes in microbial biogeography: do molecules and morphologies give the same answers? ISME J. 10, 1779-1790. doi: 10.1038/ismej.20 15.224

Santoferrara, L. F., and McManus, G. B. (2017). Integrating dimensions of biodiversity in choreotrichs and oligotrichs of marine plankton. Eur. J. Protistol. 61, 323-330. doi: 10.1016/j.ejop.2017.04.004

Shen, Z., Liu, W., Zhang, S., Yi, Z., and Liu, H. (2018). Taxonomy, morphology and phylogeny of a new oligotrich ciliate Omegastrombidium hongkongense $\mathrm{n}$. sp. (Protozoa: Ciliophora) from Clear Water Bay, Hong Kong. J. Ocean Univ. China 17, 890-896. doi: 10.1007/s11802-018-3483-0

Sherr, E. B., and Sherr, B. F. (1987). High rates of consumption of bacteria by pelagic ciliates. Nature 325, 710-711. doi: 10.1038/325710a0

Song, W., Li, J., Liu, W., Al-Rasheid, K. A. S., Hu, X., and Lin, X. (2015a). Taxonomy and molecular phylogeny of four Strombidium species, including description of S. pseudostylifer sp. nov. (Ciliophora, Oligotrichia). Syst. Biodivers. 13, 76-92. doi: 10.1080/14772000.2014.970674

Song, W., Li, J., Liu, W., Jiang, J., Al-Rasheid, K. A., and Hu, X. (2013). Taxonomy, morphology and molecular systematics of three oligotrich ciliates, including a description of Apostrombidium parakielum spec. nov. (Ciliophora, Oligotrichia). Int. J. Syst. Evol. Microbiol. 63, 1179-1191. doi: 10.1099/ijs.0. 048314-0

Song, W., Pan, B., El-Serehy, H. A., Al-Farraj, S. A., Liu, W., and Li, L. (2020). Morphology and molecular phylogeny of two freshwater oligotrich ciliates (Protozoa, Ciliophora, Oligotrichia), Pelagostrombidium fallax (Zacharias, 1895) Krainer, 1991 and Limnostrombidium viride (Stein, 1867) Krainer, 1995, with brief notes on stomatogenesis. J. Eukaryot. Microbiol. 67, 232-244. doi: $10.1111 /$ jeu.12777

Song, W., Wang, L., Li, L., Al-Farraj, S. A., Aleidan, A., Smith, S., et al. (2018). Morphological characterizations of four species of Parallelostrombidium (Ciliophora, Oligotrichia), with a note on the phylogeny of the genus. J. Eukaryot. Microbiol. 65, 679-693. doi: 10.1111/jeu.12513

Song, W., Xu, D., Zhang, Q., Liu, W., Warren, A., and Song, W. B. (2019). Taxonomy and phylogeny of two poorly studied genera of marine oligotrich ciliates including descriptions of two new species: Cyrtostrombidium paraboreale sp. $\mathrm{n}$. and Apostrombidium orientale sp. n. (Ciliophora: Spirotrichea). Eur. J. Protistol. 70, 1-16. doi: 10.1016/j.ejop.2019.05.001

Song, W., Zhao, X., Liu, W., Hu, X., Al-Farraj, S. A., Al-Rasheid, K. A. S., et al. (2015b). Biodiversity of oligotrich ciliates in the South China Sea: description of three new Strombidium species (Protozoa, Ciliophora, Oligotrichia) with phylogenetic analyses. Syst. Biodivers. 13, 608-623. doi: 10.1080/14772000.2015. 1081992

Song, W. B., and Bradbury, P. C. (1998). Studies on some new and rare reported marine planktonic ciliates (Ciliophora: Oligotrichia) from coastal waters in North China. J. Mar. Biol. Ass. U. K. 78, 767-794. doi: 10.1017/ S0025315400044775

Song, W. B., Wang, M., and Warren, A. (2000). Redescriptions of three marine ciliates, Strombidium elegans Florentin, 1901, Strombidium sulcatum Claparede \& Lachmann, 1859 and Heterostrombidium paracalkinsi Lei, Xu \& Song, 1999
(Ciliophora, Oligotrichida). Eur. J. Protistol. 36, 327-342. doi: 10.1016/S09324739(00)80010-3

Song, W. B., Warren, A., and Hu, X. (2009). Free-living Ciliates in the Bohai and Yellow Seas, China. Beijing: Science Press, 1-518. doi: 10.1016/j.ejop.2009. 12.001

Stamatakis, A. (2006). RAxML-VI-HPC: maximum likelihood-based phylogenetic analyses with thousands of taxa and mixed models. Bioinformatics 22, 26882690. doi: 10.1093/bioinformatics/btl446

Stamatakis, A., Hoover, P., and Rougemont, J. (2008). A rapid bootstrap algorithm for the RAxML web servers. Syst. Biodivers. 57, 758-771. doi: 10.1080/ 10635150802429642

Stoeck, T., Hayward, B., Taylor, G. T., Varela, R., and Epstein, S. S. (2006). A multiple PCR-primer approach to access the microeukaryotic diversity in environmental samples. Protist 157, 31-43. doi: 10.1016/j.protis.2005. 10.004

Sun, P., Clamp, J., Xu, D., Huang, B., and Shin, M. K. (2016). An integrative approach to phylogeny reveals patterns of environmental distribution and novel evolutionary relationships in a major group of ciliates. Sci. Rep. 6:21695. doi: $10.1038 /$ srep21695

Sun, P., Huang, L., Xu, D., Huang, B., Chen, N., and Warren, A. (2017). Marked seasonality and high spatial variation in estuarine ciliates are driven by exchanges between the 'abundant' and 'intermediate' biospheres. Sci. Rep. 7:9494. doi: 10.1038/s41598-017-10308-y

Sun, P., Huang, L., Xu, D., Warren, A., Huang, B., Wang, Y., et al. (2019). Integrated space-time dataset reveals high diversity and distinct community structure of ciliates in mesopelagic waters of the northern South China Sea. Front. Microbiol. 10:2178. doi: 10.3389/fmicb.2019. 02178

Tsai, S. F., Chen, W. T., and Chiang, K. P. (2015). Phylogenetic position of the genus Cyrtostrombidium, with a description of Cyrtostrombidium paralongisomum nov. spec. and a redescription of Cyrtostrombidium longisomum Lynn \& Gilron, 1993 (Protozoa, Ciliophora) based on live observation, protargol impregnation, and 18S rDNA sequences. J. Eukaryot. Microbiol. 62, 239-248. doi: 10.1111/jeu. 12173

Wang, R., Song, W., Bai, Y., Warren, A., Li, L. F., and Hu, X. Z. (2020). Morphological redescriptions and neotypification of two poorly known tintinnine ciliates (Alveolata, Ciliophora, Tintinnina), with a phylogenetic investigation based on SSU rRNA gene sequences. Int. J. Syst. Evol. Microbiol. 75, 2515-2530. doi: 10.1099/ijsem.0.00 4065

Wang, R., Song, W., Yi, Z. Z., Lin, X. F., Al-Rasheid, K. A. S., and Hu, X. Z. (2018). Morphology and molecular phylogeny of two new species of Spirostrombidium (Ciliophora, Oligotrichia), with a key to species in the genus. Syst. Biodivers. 16, 743-756. doi: 10.1080/14772000.2018.148 4393

Wang, Y. R., Jiang, Y. H., Liu, Y. Q., Li, Y., Katz, L. A., Gao, F., et al. (2020). Comparative studies on the polymorphism and copy number variation of mtSSU rDNA in ciliates (Protista, Ciliophora): implications for phylogenetic, environmental, and ecological research. Microorganisms 8:316. doi: 10.3390/ microorganisms 8030316

Wang, Y. R., Wang, C. D., Jiang, Y. H., Katz, L. A., Gao, F., and Yan, Y. (2019). Further analyses of variation of ribosome DNA copy number and polymorphism in ciliates provide insights relevant to studies of both molecular ecology and phylogeny. Sci. Chin. Life Sci. 62, 203-214. doi: 10.1007/s11427018-9422-5

Xu, D., Kong, H., Yang, E.-J., Li, X., Jiao, N., Warren, A., et al. (2020). Contrasting community composition of active microbial eukaryotes in melt ponds and sea water of the Arctic ocean revealed by high throughput sequencing. Front. Microbiol. 11:1170. doi: 10.3389/fmicb.2020.0 1170

Xu, D., Li, R., Hu, C., Sun, P., Jiao, N., and Warren, A. (2017). Microbial eukaryote diversity and activity in the water column of the South China Sea based on DNA and RNA high throughput sequencing. Front. Microbiol. 8:1121. doi: 10.3389/fmicb.2017.01121

$\mathrm{Xu}$, D., Song, W. B., and Warren, A. (2006). Morphology and infraciliature of two new species of marine oligotrich ciliates (Ciliophora: Oligotrichida) from China. J. Nat. Hist. 40, 1287-1299. doi: 10.1080/00222930600913925 
Xu, D., Sun, P., Clamp, J. C., Ma, H., and Song, W. B. (2011). The establishment of a new oligotrich genus Varistrombidium n. gen. and the morphology and phylogeny of a marine ciliate $V$. kielum (Maeda \& Carey, 1985) n. comb. (Protista, Ciliophora). Acta Zootaxon. Sin. 36, 502-511. doi: 10.1111/j.17494877.2010.00232.x

Xu, D., Sun, P., Warren, A., Noh, J. H., Choi, D. L., Shin, M. K., et al. (2013). Phylogenetic investigations on ten genera of tintinnid ciliates (Ciliophora: Spirotrichea: Tintinnida), based on small subunit ribosomal RNA gene sequences. J. Eukaryot. Microbiol. 60, 192-202. doi: 10.1111/jeu.1 2023

Xu, D., Warren, A., and Song, W. B. (2009). "Oligotrichs," in Free-living Ciliates in the Bohai and Yellow Seas, China, eds W. Song, A. Warren, and X. Hu (Beijing: Science Press), 307-351. doi: 10.1016/j.ejop.2009. 12.001

Yang, J., Huang, S., Fan, W., Warren, A., Jiao, N., and Xu, D. (2020). Spatial distribution patterns of planktonic ciliate communities in the East China Sea: potential indicators of water masses. Mar. Pollut. Bull. 156:111253. doi: 10.1016/ j.marpolbul.2020.111253
Conflict of Interest: The authors declare that the research was conducted in the absence of any commercial or financial relationships that could be construed as a potential conflict of interest.

The handling editor declared a past co-authorship with one of the authors LL.

Publisher's Note: All claims expressed in this article are solely those of the authors and do not necessarily represent those of their affiliated organizations, or those of the publisher, the editors and the reviewers. Any product that may be evaluated in this article, or claim that may be made by its manufacturer, is not guaranteed or endorsed by the publisher.

Copyright (๑) 2021 Song, Xu, Chen, Warren, Shin, Song and Li. This is an open-access article distributed under the terms of the Creative Commons Attribution License (CC BY). The use, distribution or reproduction in other forums is permitted, provided the original author(s) and the copyright owner(s) are credited and that the original publication in this journal is cited, in accordance with accepted academic practice. No use, distribution or reproduction is permitted which does not comply with these terms. 